IRA-International Journal of Management \& Social Sciences

ISSN 2455-2267; Vol.04, Issue 01 (2016)

Institute of Research Advances

http://research-advances.org/index.php/RAJMSS

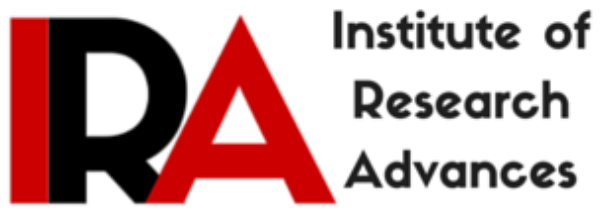

\title{
The Glorious Days of Silk Trade in Malda District and Its Legacy
}

\author{
Sagar Simlandy, \\ Assistant Professor in History, \\ Sripat Singh College, \\ Jiaganj, Murshidabad, India.
}

DOI: http://dx.doi.org/10.21013/jmss.v4.n1.p10

How to cite this paper:

Simlandy, S. (2016). The Glorious Days of Silk Trade in Malda District and Its Legacy. IRA-International Journal of Management \& Social Sciences (ISSN 2455-2267), 4(1). doi:http://dx.doi.org/10.21013/jmss.v4.n1.p10

(C) Institute of Research Advances

(oc) EY-NC

This works is licensed under a Creative Commons Attribution-Non Commercial 4.0 International License subject to proper citation to the publication source of the work.

Disclaimer: The scholarly papers as reviewed and published by the Institute of Research Advances (IRA) are the views and opinions of their respective authors and are not the views or opinions of the IRA. The IRA disclaims of any harm or loss caused due to the published content to any party. 


ABSTRACT
With its glorious traditional identity of Malda as a district is associated with the history of India
for ages past. Malda is famous for its silk which claims credit for its familiarity in the whole India.
Kautilya stated its glory in his 'Arthosastha'. This sericulture has got its extreme in the district of
Malda in the Ancient and Mediaeval times but it loses the glory due to Industrial Revolution in
England. The East India Company has exported the Muslin of Malda in the entire World and made
high profit that time. But the employer i.e. East India Company deprived the weavers of Malda in
many forms to extract a high profit in silk trade. Eventually the weaver left the profession. As a result
the production of Muslin was drastically reduced. Despite this deprivation and oppression, many
weavers were engaged in that profession. Muslin weavers tried their best to make their product
familiar throughout the country and outside the country. But they failed due to atrocities of the
English East India Company. The Muslin was so famous that if it got its due patronage then it could
be the forerunner of Industrial Revolution in India. Instead England got the Industrial Revolution in
the Textile industry. The Article tries to emphasise the point and tries to explain reason behind it.

Keywords: Tradition, Industrial Revolution, Muslin, East India Company, Malda

With its glorious traditional identify district Malda is associated with the history of India for ages in the past. In the political history it is known as Gauda Pundabardhan. The capital Gauda and Pundranagari were once the two eminently great cities in the Eastern India. Triumphal progress with grand war-trumpets and drums had been a frequent phenomenon about this capital city and likewise innumerable production-centres of silk industry flourished in this cities. ${ }^{1}$ Hence tradition was initiated. Industry fields grew up in the annexed townships of these capitals and grand trade of silk was initiated to the admiration of all, here and abroad. The murmuring rhythms of thousands of hand operated looms signified rich silk fabric production enriching the treasury with profuse gold coins ${ }^{2}$ That glorious tradition continued over centuries. Despite its grand decadence, that silk industry retains its existence still today. Deplorable though its condition is, it has latest possibilities yet these days.

Silk industry had been of high merit in Malda ever since the older times. There has been reference to a kind of silk fabric of Pundabardhan even in the "Arthashastra" of Kautilya. ${ }^{3}$ Colour of that silk was black and its smoothness was like that of precious gems. Besides these, two special kinds of silk was produced named "Kshauma" "Dukul" and their demand was worldwide.

In older times silk producers in Gauda were called 'Pundarikasha', and the term originated from 'Pundarika' the name of silk worm there in these days. This silk fabric of Gauda was called then 'Pattabastra'. Some time in between, during the invasion by the Muslim, proscription was imposed on production of that pattabastra; but releasing the commercial importance that production was revived. Production of high quality silk fabric at Gauda-Malda has been referred to in Aain-e-Akbari. In 1577 A.D. ${ }^{4}$ an eminent merchant Shaikh Vik of Gauda-Malda had been to Russia taking merchandise of three ship loaded of silk. Of these three, unfortunately two ships soak in the Gulf of Persia; yet trading in Russia silk goods of only one ship that merchant amassed huge fortune.

Since times long past demand of silk throughout our country and abroad was fulfilled by supply from this Malda district. Attracted by those treasure-houses of silk at Malda (Old Malda) the Dutch's built up trade centres there. ${ }^{5}$ Provoked by this the East India Company too decided to build up their own trade centres there. In April, 1680 Matthews Vincent, the chief of the commercial affairs of the East India Company negotiated with Mr. Littleton of Cossimbazar Commercial House and with the Commercial House at Malda established the Commercial House of the of the East India Company at the confluence field of rivers Kalindi and Mahananda. In those days' merchants from Gujarat, 
Agra, Benaras, Mysore and such other places over India thronged at Malda to trade on silk and related commodities. The English merchants studied that price of silk at Malda was cheaper than that at Kapis- Market in Dacca ${ }^{6}$ So they selected Malda as the principal trade centre of Bengal.

In two years from establishing commercial firm(1582) East India Company at Malda exported profuse silk products to foreign countries, and the details are as follow: Kora Muslin-13000 rolls, Malmal Muslin-15000 rolls, Tantisab Muslin-10000 rolls, Mirwand fine Muslin-500 rolls, Sir Sukars Muslin-4000 rolls, Rehing Muslin-3000 rolls, Jamjam Muslin-4000 rolls, Adatin fine Muslin-15000 rolls, Mandim(mixed and chequered) Muslin-10000 rolls, Elachi (mixed) Muslin-12000 rolls and Taffeta-20 bales. This commercial deseription indicates the huge quantity and large variety of excellent silk production at Malda in those times ${ }^{7}$ and all by our own weavers. These Besides, at Gauda town and adjacent human habitation there had been a professional artisans known as Rangrej' who decorated the silk fabric with colour, gold and silver threads and wade of them very much attractive. East India Company earned huge profit exporting these colourful silk products to foreign countries. ${ }^{8}$

By and by the East India Company took the silk market in Malda in its full control. We may have a look into the commercial relation between Fort William and India House and perusing its details it is found whereas East India Company invested Rupees 1,69,720 for Calcutta trade, Rs. $1,68,500$ for Santipur, for Sonamukhi 1,69,720, for Malda it had invested Rs. 3,52,450. What a large demand it grew for silk products from Malda! It had been Malda where the East India Company invested such a large amount of money to capture the market, and so it was necessary to enhance supply of silk product from Malda. Cultivators and weavers of Malda employed their full endeavour to cater to this growing demand of the English traders, and so countless looms were installed by the weavers. Based on that synchronised endeavour Malda became a place fit for an industrial revolution. ${ }^{9}$ The ground was congenial for that part of revolution and that besides, the English left no competitor for that.

So continuing, India faced that great historical- political event, the Battle of Plassey in 1757 in which the English East India Company achieved victory. ${ }^{10}$ Consequently the environment of cooperation of the cultivators and the weavers was no more. Elated with victory and pride the English East India Company inflicted inhuman torture and exploitation upon the weavers and cultivators of Gauda. Their ulterior motive was exorbitant profit and prosperity of their homeland. The Company made it compulsory that the silk producers of Gauda and Malda would have to sell their produce only to the English East India Company, and none else. They would have to supply silk produce by the date fixed by the Company, which they would have to pay heavy fine. ${ }^{11}$ That is, they had to produce and weave silk in compliance of the demand of the Company. Even Queen Elizabeth was allured to have her own dresses from the exquisitely fine muslin woven by the weavers at Malda. The weavers were compelled to sell their silk products at a very low price to the agents of the company. Advance loan system was replaced by agency system. Failing to supply silk products at low price the ruling staff of the Company would inflict inhuman torture upon them. ${ }^{12}$ The Company having the paramount rule at Malda, There was none to contradict them. Besides that, the Company

The system of loan as earnest money was replaced by Agency System. Failing to produce silk fabric on low price the weavers faced tremendous torture in the hands of the Company officials and subordinate. The Company being the supreme authority. Besides these, monopoly of raw cotton was in the absolute control of the Company. So purchasers were compelled to buy cotton from the company agents, and at exorbitant rate. So the weavers were compelled to leave here. ${ }^{13}$

Just at such crucial junction of time there was industrial Revolution in England in 1760; and on that account the Industrial feature of England as well as Malda underwent a radical change. $67.5 \%$ tax was imposed on calico cloth imported from India and 37.5\% tax on Indian Muslin. ${ }^{14}$ Lion's share of that Indian Muslin was from Malda. Only raw silk was wanted from the weavers of Malda. Production of silk fabric was closed. ${ }^{15}$ The Company inflicted merciless torture and exploitation upon the Muslin-producing weavers. All prospect of the industrial silk production of Malda was crippled and of the silk weavers withal. Fabric from Manchester and Lanchashire began to capture the silk market of Malda. All prospect of industrial growth of silk was thus dwindled in a hundred years from 
establishing the industrial centre in India and Malda. Under British Supervision in 1680; and the entire administration of Bengal was hinged on the British East India Company. ${ }^{16}$

Thomas Headman set up a resident by transforming a protected business centre in EnglishBazer in 1771. This residence became the centre at power of the Britishers. It is now called "Court Building". The East India Company invested much in this resident because the gradual increase of this trade. For this reason supply was needed. ${ }^{17}$ The person engaged in this sericulture and weavers of this trade tried their best to fulfil the demand of Muslin. This was how the Industrial Revolution would had been happened because the situation of English-Bazer in Malda was favourable for this in all sense comparable to every Revolution happened in the World which History told. ${ }^{18}$

During Plassey War in Bengal there was a feminine happened. It was a curse to this trade in Malda. This feminine hammered the most to Purnia Zilla and mostly part of Malda. ${ }^{19}$ Despite the weavers of Malda continued their weaving this Muslin. Then the cost of fine Muslin was Rs. 2 and 4 Anna per sher. The economic condition of the people was damaged by the feminine. But the cost of fine Muslin was Rs. 6 and 4 Anna per Sheer after that. When the people of Malda retained this trade, ${ }^{20}$ the East India Company increased their torture to those people. Their sole intention was to control over this production of the trade entirely torturing them so that they would be depended. The Hero of this torture was Woodni. ${ }^{21}$

The weavers at this trade of Malda continued their production with fewer wages then, but the condition of torture did not lesson. For example, one weaver at Haripal got wage Rs. 16 and 13 Anna but one weaver of Malda got Rs.11 and 12 Anna. ${ }^{22}$ Then all the weavers of Malda compelled to protest and revolt untidily against this oppression and torture. They denied supplying this Muslin to the East India Company. This revolt became heavy in the last decade of 18th century. ${ }^{23}$ That fiuse the commercial Resident Mr.Taylor lodged a criminal case against the weavers of Malda and started to give them punish. Despite the famous of Malda 'Uranka'(production centre of this Muslin) namely. Kaliganj, Jagannathpur, Sharupganj etc. Continued their production and this industry did not lose its glamour. $^{24}$

Despite the Industrial Revolution of England and the oppression at the Britishers the demand Muslin was crazy to the people of the whole World. ${ }^{25}$ The weavers of Malda got benefit at road communication to the other part of Bengal and India also to fulfil the demand. The communication at Malda to the Rajmahal Patna, etc. through submarine was good by water and by road from Malda people and goods brought to Baniakhali, Tamluk, Budge Budge, Cossimbazar etc. easily. ${ }^{26}$ The road communication and water ways communication were good in every sense. As a result there was no problem to continue carry goods to the other part of Bengal and India also still, Malda Muslin was the most preferred silk to the Rajparibar or Queens choice. ${ }^{27}$

\section{Conclusion:}

Despite a lot of problems people of Malda are still active to revive this industry of Muslin. Some weavers are producing "Naksha par Saree" by using a machine in their 'Tant' with the use of Chittaranjan Model of 'Tant'. Their new models of saree have made a demand in the market. If our country the Central Govt. Cottage Industry helps them, this demand will increase unquestionable. It is true that emotion and sentiments to their profession, feeling of self respect, patriotism to their country, feeling of own country Nationalism is merit of a class country. This should be ..... by the all their from higher to lower of our country Govt. It will cause the increase of demand of Muslin in the market definitely. Not only the people of Malda are proud of it but we the people of India are proud also. It is the sole economic existence of the people of Malda. We must not lose its glamour because it is our identity. If we deny it, it is the denial of our ancestors. It is not using but death of heritage. I have tried my best through this Article to highlight the glorious past, present problems and future possibility of this industry expecting a fruitful result to revive this industry. 


\section{References:}

1.W.W. Hunter, The Annals of Rural Bengal, Trubner and Co. Landon (1868), pp-121-123.

2. F. Ellies, Rural Livelihoods and Diversity in Diversity in Developed Countries, Oxford University Press, New York, 2001, pp-215.

3. E. Durkheim, The Division of Labour in Society, Macmillian, New York, 1964, pp-37-38.

4. H.B. Morse, Chronicles of the East India Company Trading to China, 1635-1834, Clarendon, 1926, pp-311.

5. http://www.csb.gov.in/silk-sericulture/silk

6. T.D.Koshy, Silk: Production and export management, Macmillian, New York, 1968, pp-240-243.

7. Ibid. Pp-99-101.

8. N. Tamanna, Handbook of Silk Technology, Sonwalker, 1987, pp-56-59.

9. Ibid. Pp-394-395.

10. M. Greenberg, British Trade and the Opening of China, 1800-1842, Cambridge University Press, 1951, pp-171-172.

11. Peter Hopkirk, Foreign Devils on the Silk Road, Oxford, U.P, 1980, PP-72-76.

12. Ibid. Pp-95-96.

13. http://www.csb.gov.in/silk-sericulture/silk-of-India/.

14. K.K. Dutta(ed). Fort William- India House Correspondence Vol.-1, 1748-1756, National Archaives.

15. B.D. Basu, The Ruins of Indian Trade and Industries during British Raj, Discovery Publisher, Landon, 1989, pp-85.

16. Idib. Pp-78.

17. W.W.Hunter, AStatistical Account of Bengal (Maldah), Trubner And Co., Landon, Vol.-7, 1976, pp-112-113.

18. Idib. Pp-225.

19. S.Bhattacharya, The East India Company and the History of Bengal, Trubner and Co, Landon, 1982, pp-135-137.

20. R.C.Dutta, The Economic History of India Under the Early British Rule, Vol.-1, Trubner and Co. , Landon, 1902, pp- 195-196.

21. B.Roy, Cencus-1961, Malda.

22. Debendra Bijay Moitra, The Cotton Weavers of Bengal, (1757-1838), Firma Publisher Culcutta, 1997, pp-117-118.

23. Ibid. Pp-221-222.

24. Feild Study of Many Village of Villagers of Malda.

25. Dr. Tusher Kanti Ghosh, Khadi Gramin Shilipo Barta, Malda-2012, pp-15-18. 
26. Ibid. Pp-43-46.

27. G.E.Lambourne, Bengal Districts Gazetters Malda, HDRCC, West Bengal-2007. 